\title{
Use of low potencial wastewater heat
}

\author{
Vladimir Dmitrienko ${ }^{1,}{ }^{*}$, Nataliya Merenkova ${ }^{1}$, Irina Zanina ${ }^{1}$, and Nadezhda Dmitrienko ${ }^{1}$ \\ ${ }^{1}$ Don State Technical University, Institute of service and business (branch) of Don State Technical \\ University, 147 Shevchenko, 346500 Shakhty, Russia
}

\begin{abstract}
The article points out that exhaustion of fossil stocks of fuel and negative impacts of fuel burning on environment determined a significant interest in technologies of heat utilization of low-potential sources in many developed countries of the world. Therefore the solution of the problem of using heat utilization technologies of low-potential sources will be of great importance for preserving people's habitats. In Russia, the most promising area of using unconventional energy sources is heat supply systems of houses and buildings. The conducted analysis shows that one of the effective directions of energy saving is heat pump systems of heat supply, using the most available low potential heat source of flooded massif of soil. It is noted that a huge energy potential of water pumped from closed mines is practically unused because of considerable distance of heat consumers from water purification complexes.
\end{abstract}

\section{Introduction}

In modern conditions of growing demands for energy resources and reduction of easy recoverable reserves of traditional energy sources, the issue of energy saving becomes especially important. The energy crisis of the nineties of the last century stimulated the development of energy technologies using unconventional energy sources [1].

The state program for improving energy saving and energy efficiency for the period until 2020 is intended to preserve 170-180 million tons of conventional fuel [2]. For European countries, energy consumption in homes is about $10 \mathrm{kWh} / \mathrm{m}^{2}$, and in Russia it is $400-600$ $\mathrm{kWh} /$ year per square meter [3]. These indicators are expected to be reduced by $45 \%$ by 2020. Therefore, non-traditional energy sources as the main tools of energy saving should become one of the main incentives of economic development in this country.

\section{Analysis of low-potential heat sources}

Most production enterprises are accompanied by both consumption and release of a great amount of thermal energy known as low potential energy dispersed in the environment. The main sources of low-potential energy are natural sources of heat: land, water, air; or artificial sources (secondary energy resources), i.e., thermal waste (industrial wastes, domestic heat, vented air) [4-6]. The energy potential of the above mentioned sources is huge.

The thermal regime of upper layers of the Earth is formed by means of solar radiation and the flow of thermal energy from the earth's interior, being natural thermal accumulator. The temperature regime of the upper zone of $15-20 \mathrm{~m}$ of soil mass is determined by penetration

\footnotetext{
* Corresponding author: vadmitrienko@rambler.ru
} 
of seasonal air temperature variations and the intensity of solar radiation which does not exceed, as a rule. The temperature of rocks located below this zone is not subject to significant fluctuations and is determined by heat from the bowels of the Earth. Accordingly, aquifers located at a depth more than $20 \mathrm{~m}$ will have almost constant temperature, increasing by $3^{\circ}$ $\mathrm{C}$ at every $100 \mathrm{~m}$ of depth.

In the mining regions, the amount of water pumped to the surface can reach thousands of $\mathrm{m} 3$ / h. For example, in Russian East Donbass an average amount of water is 3 м pumped out for a ton of coal. Even after closure of mines it is necessary to pump out water from old mining workings since there is a threat of flooding for some residential areas. In this case, the volume of low-potential heat that can be utilized is practically inexhaustible.

\section{Ways of utilizing diffused heat}

The main objectives of energy saving in Russia can be applied for the following areas: modernization of production with energy-efficient technologies and equipment; - Increasing the energy efficiency of buildings and structures; - Means stimulating consumers to rational use of electricity by means of organizational and regulatory measures, tariff policy, subsidizing energy efficiency of facilities [7].

One of the most effective ways of saving organic primary fuel in heat supply systems is the use of heat pump plants allowing transforming low-temperature renewable natural energy and secondary low-potential heat to higher temperatures suitable for heat supply [8-11]. Heat pumps use (utilize) diffused heat of natural (thermal energy of water, air, soil) or technogenic origin (heat of industrial and sewage water, ventilation pipes and flue gases, technological processes, etc.). The heat pump is compatible with any circulating heating and ventilation system. Thermodynamically, the heat pump is similar to a refrigerating machine. However, if in the refrigerator the main purpose is to produce cold by means of taking heat from the evaporator and the condenser emits heat into the environment, in the heat pump the picture is reversed.

The condenser is a heat exchange apparatus generating heat for the consumer, and the evaporator is a heat exchanger utilizing low-potential heat: secondary energy resources and (or) non-traditional renewable energy sources [12].

In the housing and communal sector, one of the most progressive ideas in the sphere of energy saving is the construction of so-called "passive houses", in which the energy consumption is 10 times less than it is consumed by the majority of operated buildings. The achievement of such indicators is possible only by means of using the systems of recuperation of supply and exhaust ventilation and water disposal. The experience of Germany, Denmark and other European countries shows that government initiatives stimulating consumers, allow getting impressive results. The number of "passive houses" in Europe reaches thousands [13].

Thanks to the current State Energy Saving Program adopted in 2010, there are several examples of building energy-efficient houses in Russia. In Moscow, several experimental buildings have already been built using passive house technology (a house in Nikulino-2). A demonstration project of such house is also built near St. Petersburg. The construction of the first settlement of passive houses was started near St. Petersburg. Since 2010, the experimental construction of energy-efficient houses for settling people from dilapidated and emergency houses is being financed by the Housing Fund. At the beginning of 2011, several energy-efficient buildings with the Fund's participation have already been built in different regions of Russia. The first certified passive house was built in Russia in 2011 by the company "Mosstroy-31" under the project of Thomas Knecht. The specific heat consumption for heating is $24 \mathrm{kWh} / \mathrm{m}^{2}$ a year [14-15]. 
One of the main problems of using low-potential thermal energy in the national economy is the ways of its transportation. Part of the heat energy is lost during transportation - it escapes through the thermal insulation of the pipes (as the insulation cannot be ideal). These losses are considered to be technological (inevitable), they cannot be eliminated completely, although they can be reduced due to the qualitative insulation of the pipes, including their replacement with pipes made of more perfect materials, but it requires great investments. The same situation arises with the accumulation of low-potential thermal energy. The process of accumulating such energy is completely non-rational, since the same losses occur, as, for example, during transportation [16].

This problem is especially acute in small towns of the coal-mining regions. On the one hand, a huge amount of low-potential heat is emitted into sumps on the other its utilization is not possible due to a significant distance of treatment facilities from dense urban districts with a large consumption of thermal energy.

\section{Analysis of the drainage complex in the town Shakhty of Rostov region}

Until the mid of 90 s of the last century, there were 10 mining enterprises in this town, which were closed at the beginning of the 2000 as diversification program of the coal industry. The absence of pumping out groundwater from the mines led to great increase of water levels. To prevent flooding of residential areas due to increase of groundwater level after mines closure in town Shakhty, the organization "Operation of pumping stations" was established to pump water out of old mine workings and cleaning it.

There are three sites in the town to pump out and purify water from old mine workings Uzhnaya, Mayskaya and Glubokaya. The total volume of pumped water exceeded $1500 \mathrm{~m}^{3} / \mathrm{h}$ with temperature from $12^{\circ} \mathrm{C}$ to $26^{\circ} \mathrm{C}$. Thus, the availability of mine water is possible due to large pumping volumes in the coal-mining regions, even after closure of the mines. The technical realization of generating energy from purifying mine water can be carried out with the help of widely used heat pumps [17-18]. In this case, the first heat exchange circuit or the low-potential heat collection system can be made in accordance to the simplest and cheapest scheme consisted from successively (or parallel) connected pipes. They can be located directly in the mixer, aerator or sumps [19-20]

The spectrum of heat pumps produced by foreign and domestic manufacturers is wide. Therefore, it will be easy to select a model of the required capacity to raise the temperature in the second circuit to the required temperature.

There are example of models of obtaining deep cold, combined (heat-cold) and heat.

According to the leading organizations specializing on this subject is "Insolar", stating that savings can reach $75 \%$, and this is practically the received result [25]. This organization together with the Government of Moscow implemented, , a number of projects in the cities of Zelenograd, Yaroslavl and Moscow. As a result of the carried out works it was established that heat pump systems of heat supply (HPS) allow: to reduce the installed electric power of heat-generating equipment in $1,5 \div 2$ times; to reduce operational costs in comparison with gas boilers or liquid boilers in $1,5 \div 2,5$ times.

Currently, the technology of utilizing the energy of mine waters is used at the heat pump station HPS-1 in Novoshakhtinsk, the construction of which was carried out in the town center to provide heat to social facilities.

The station includes: 2 heat pumps, each with the capacity of $0.382 \mathrm{MW}, 3$ gas boilers with the capacity of $2 \mathrm{MW}$ each. It works with a reverse cycle of water, the inlet of which is carried out from a specially drilled well. The temperature of the mine water at the inlet is $18^{\circ} \mathrm{C}$, at the outlet is $-12^{\circ} \mathrm{C}$. At a flow rate of $100 \mathrm{~m}^{3} / \mathrm{h}$, the temperature of the water to the 
heating system and to the hot water system is $65^{\circ} \mathrm{C}$. Total heat production is $11,391 \mathrm{Gcal} / \mathrm{per}$ year. Savings due to reduced fuel consumption are 34,248.50 thousand rubles a year.

HPS-1 makes a significant contribution to the ecology safety of the region. For the year of operation of the energy complex, the gas consumption is reduced by 4 times, and coal consumption is reduced by almost 22 times. This allows reducing the emission in the atmosphere of more than 39 tons of harmful substances and save more than 2.5 thousand tons of atmospheric oxygen. The reduction in emissions for the year is: carbon oxides - 1.6; carbon dioxide - 3,2; sulfur oxide - 509.3 times.

Unfortunately, this object is the only one in our region. This is due to the fact that a great majority of mines were located in the settlements. Accordingly, existing treatment facilities are located far away from large heat consumers.

The possibility of using low-potential groundwater heat is analyzed by means of using the example of treatment facilities complex of the former Glubokaya mine. The complex of facilities includes: two submersible pumps with a capacity of up to $930 \mathrm{~m} / \mathrm{h}$; a mixer, an aerator and four sumps (sedimentation tanks). The whole complex is clearly visible in the photograph from the satellite (Fig. 1).

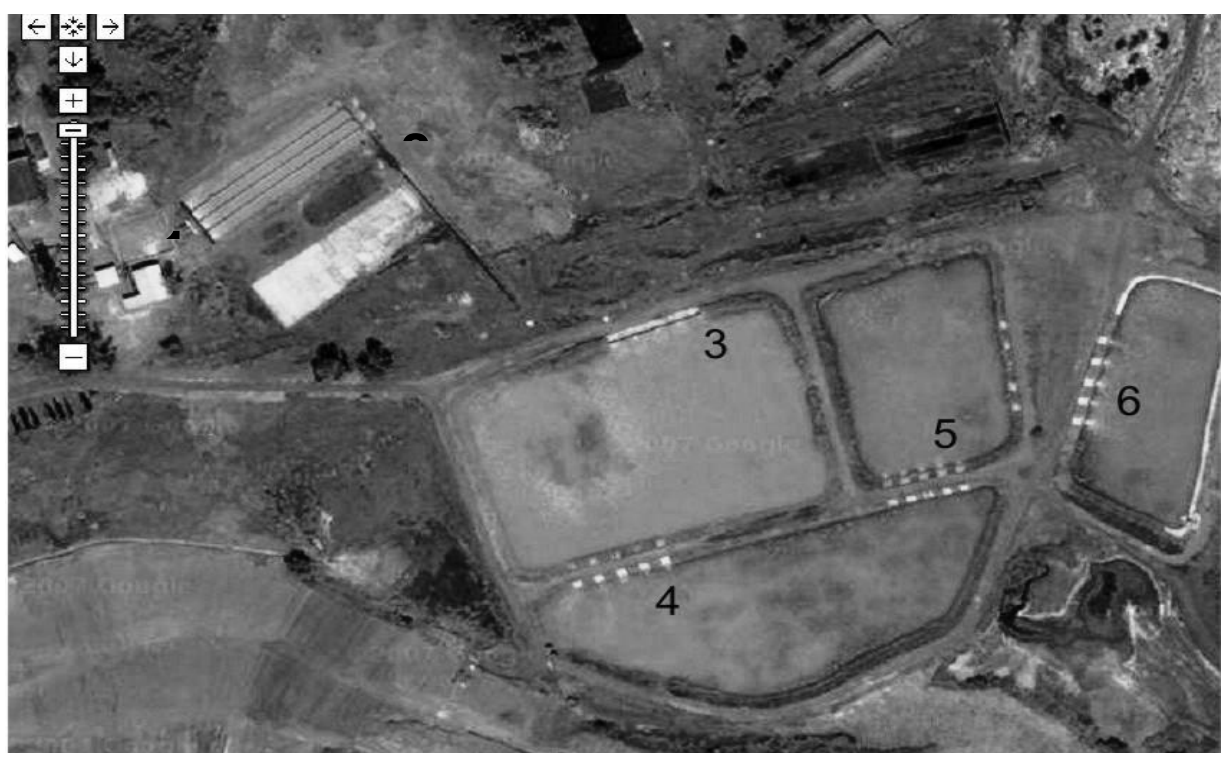

Fig. 1. A complex of treatment facilities on the territory of the former "Glubokaya" mine: 1 - a mixer; 2 - aerator; 3 - the first pond sump; 4 - the second pond sump; 5 - third pond sump; 6 fourth pond sump

The water pumped by submersible pumps from the main shaft of the mine gets into the damper of the hydraulic hammers and further to the mixer, aerator, first, second, third and fourth ponds of sumps. Before leaving the second pond of sump, the temperature of the water is $+19^{\circ} \mathrm{C}$ all year-round. Further to the exit from the treatment facilities it falls to $+17^{\circ} \mathrm{C}$.

Water, located in a mixer, aerator, in the first and second ponds of sumps is considered to be a source of low-potential geothermal heat. Its volume at the depth of the mixer and aerator is $3.0 \mathrm{~m}$, and ponds of $2.5 \mathrm{~m}$. are about $50,000 \mathrm{~m}^{3}$. It is impossible to discount the third and fourth ponds of clarifiers with a volume of about $18,000 \mathrm{~m}^{3}$, where the temperature of water drops only in two degrees. That is, with the utilization of the heat of the pumped water and the decrease in its temperature by only $1.1 \mathrm{C}$, one can get $1 \mathrm{Gcal} / \mathrm{hr}$ or $8760 \mathrm{Gcal}$ /per year, or $8760 \mathrm{Gcal} /$ per year, which is comparable to the capacity of the above described energy complex. 
Despite the obvious advantages of utilizing low-potential geothermal heat of mine waters, it is impossible to attract investors for the implementation of a pilot project, since the nearest consumers are located at a distance of $2 \mathrm{~km}$ from the complex of treatment facilities. This requires significant initial investments in the construction of heating mains.

The situation is complicated by the fact that the main consumers are located at a distance of $0.9-2.1 \mathrm{~km}$ that is practically in diametrically opposite direction. In accordance to the task of the Municipal Authority concerning "Operation of water drainage installations" in town Shakhty, the carried out analysis defined three sections of town boiler houses to be equipped with heat pumps. The length of the pipeline will be $2.8 \mathrm{~km}$. Calculations prove the efficiency of it even taking into account the heat losses occurred in the pipeline about 44.75 $\mathrm{kW}$, with the intake of $80 \mathrm{~m}^{3} / \mathrm{h}$ of purified water from the fourth settler and the temperature decrease in each boiler house by $3^{\circ} \mathrm{C}$, the outlet water temperature will be $4-6^{\circ} \mathrm{C}$.

However there is very serious limiting factor. The relief of the place is that in case of a pump stopping, the pipeline can be frozen at low air temperature. It has happened once when clarified water was being supplied for technical needs of brick factory.

To solve this problem, a method of monitoring the water temperature in the pipeline using the MicroLAN network and DS1820 temperature sensors has been developed. High reliability of components, simplicity of technical solutions and minimum price determine the choice of the monitoring system. In addition, the 1-Wire bus simultaneously allows controlling the operation of actuate mechanisms (a crane for emergency water dropping), both manually and automatically.

A specially developed application allows the operators visually monitoring the temperature in dangerous areas of the boiler house in the dropping area and pump installations on the supply pipeline. As a result of the experimental works it was established that stable operation of the system is achieved by the tire length of twisted couple of $240 \mathrm{~m}$ and the installation of two sensors. The distance to dropping points is almost $500 \mathrm{~m}$. So, the approach to creating a module implementing a wireless self-organizing network using $433 \mathrm{MHz}$ non-licensed frequency range is considered. The block diagram of the module being developed contains three main components: a microprocessor unit; digital transceiver of $433 \mathrm{MHz}$ range; temperature measuring unit.

The microcontroller is adopted by STMicroelectronics, implemented on the Cortex-M0 core, due to the specific features like extremely low price and low power consumption. Out of the huge number of chips and modules of digital transceivers in the $433 \mathrm{MHz}$ range, the chip CC1101 of Texas Instruments was selected. The general algorithm of constructing the MESH network is designed in such a way that the device can operate in the base station or in the subscriber mode. The entire network is constructed in such a way that, at the request of the base station, the user's data packets can reach the base station by retranslation or directly. This will allow normal monitoring of temperature, and in case of an accident, to transfer the command to emergency water dropping.

The developed solutions were handed over to the Municipal management commission "Operation of pumping stations" for consideration at the technical council.

\section{Conclusion}

Nowadays heat and cold supply systems using heat pump plants (HPPs) utilizing low-potential heat of the Earth are becoming increasingly widespread, as they represent a reliable source of energy that can be used everywhere and for a long period of time. One of the promising directions is the use of water from mines and tunnels as a source of low-potential thermal energy, since it is accessible and its temperature is constant throughout the year. This will reduce the consumption of organic fuel and minimize the cost of heat. 
The experience of European countries and the growth of state support in our country, contributes to the introduction of new technologies and the increase in the number of facilities using the principles of energy and heat saving. At present, the volumes of unused low-potential heat in the form of pumped-out mine waters in the coal-mining regions of Russia are simply enormous. Therefore, the problem of the widespread use of mine water energy is very great. However, the solution of this problem is complicated by the inability to transport and store this heat sources without significant investment. Thus the main way of recycling such heat sources is the use of heat pumps.

\section{References}

1. D. Boer, M. Medrano, M. Nogues Int. J. Of Thermodynamics, 8, 4, 12 (2005)

2. A. Costa, V. Neuhann, J. Vaillancourt, PAPTAC 90th Annual Meeting, B, 191 (2004)

3. Global Greenhouse Gas Emissions Data EPA. Climate Changes. Emissions. URL: https://www3.epa.gov/climatechange/ghgemissions/global.html.

4. G. Vasil`ev, Zhurnal «ZhKX», 12, 12 (2002)

5. V. Derizemlya, Molodoj ucheny`j, 2, 106 (2017)

6. A. Dzindzela, A. Sizyakin, E`nergosberezhenie, 1, 24 (2012)

7. D. Zakirov, A. Ry'bin, Ispol'zovaniye nizkopotentsial'noy teploty, Book 1 (RUSAJNS, Moscow, 2015)

8. V. Mukazhanov, S. Abil’dinova, L. Vasil’chenko, Vestnik AIES, 3, 21 (2008)

9. O. Povarov, G. Tomarov, Teploenergetika, 2, 74 (2010)

10. D. Re`j, D. MakMajkl, Teplovyye nasosy (E`nergoizdat, Moscow, 1982)

11. V. Saenko, TEK, 4, 124 (2004)

12. V. Slepchenok, A. Rondel', N. Shapovalov, Novosti teplosnabzheniyae, 6, 73 (2002)

13. O. Sotnikova, V. Mel kumov, Uchebnoe posobie po teplosnabzheniyu (Associacii stroitel'ny'x vuzov, Moscow, 2009)

14. Yu. Tabunshhikov, M. Brodach, N. Shilkin. E`nergoe`ffektivny`e zdaniya (AVOKPRESS, Moscow, 2003)

15. V. Fajst, A. Eloxov, Osnovny'e polozheniya po proektirovaniyu passivny'x domov (ASV, Moscow, 2008)

16. D. Zakirov, A. Ry`bin, Ispol zovanie nizkopotencial noj teploty, Vol. II (RUSAJNS, Moscow, 2015)

17. Federal’ny’j zakon Rossijskoj Federacii ot 23.11.2009. No 261-FZ "About energy saving and about increasing energy technical efficiency and about introducing amendments to certain legislative acts of the Russian Federation" (2009)

18. V. Xarchenko, V. Chemekov, Trudy 8-oy spetsializirovannoy vystavki i nauchno-prakticheskogo seminara «Izdeliya i tekhnologii dvoynogo naznacheniya. Diversifikatsiya OPK», 108 (2007)

19. V. Xarchenko, A. Sy`chyov, ISJAEE, 07, 31 (2013)

20. A.B. Yanovskiy, Yu.L. Baron, et al. Russian Energy. Lookin to the future (Publishing House Energiya, Moscow, 2010) 